\title{
USULAN PERBAIKAN MIXING DESIGN PRODUK SINTER ORE DENGAN MENGGUNAKAN METODE SIMPLEKS
}

\author{
Sahrupi ${ }^{*}$, Muhamad Abdul Kirom Maulana, Muhamad Bob Anthony \\ Program Studi Teknik Industri, Fakultas Teknik, Universitas Serang Raya \\ Email: sahrupi@gmail.com; abdulkirom120@gmail.com; tonipbm@yahoo.com
}

Artikel masuk : 14-08-2020

\author{
Artikel direvisi : 29-12-2020 \\ *Penulis Korespondensi
}

Artikel diterima : 31-12-2020

\begin{abstract}
Abstrak - Sinter ore merupakan produk setengah jadi dalam pembuatan baja. Produk ini dihasilkan dari perpaduan (mixing) raw material dibagian sinter plant untuk mendapatkan karakteristik produk baja yang berkualitas. Berdasarkan hasil identifikasi masalah di bagian Sinter Plant, ditemukan bahwa proses produksi produk sinter ore masih belum efisien. Hal ini dibuktikan dari komposisi material hasil mixing design produk cenderung melebihi target properties proses mixing design yang diinginkan oleh perusahaan. Penelitian ini bertujuan untuk mencari nilai efisiensi biaya produksi produk sinter ore dan dapat mencapai target properties produk sinter ore yang ditetapkan oleh perusahaan. Penelitian dilakukan dengan menggunakan data karakteristik produk yang menjadi target properties dalam mixing design produk sinter ore tahun 2019. Perhitungan mixing design dengan menggunakan metode simpleks. Pengolahan data dengan menggunakan metode simpleks dilakukan dengan cara eliminasi secara iteratif sebanyak 5 kali perhitungan sampai diperoleh solusi optimal. Penerapan metode simpleks dalam pengolahan mixing design produk sinter ore menghasilkan nilai efisiensi yang cukup signifikan bagi perusahaan. Nilai efisiensi yang dapat dicapai sebesar 1.050.210 USD berdasarkan penurunan biaya mixing design dari semula sebesar 20.445.600 USD menjadi sebesar 19.395.390 USD. Pencapaian target properties komposisi material hampir mendekati target yaitu fines ore $A$ sebesar 0,8997 , fines ore $B$ sebesar 0 , fines ore $C$ sebesar 0,0027 , concentrate sebesar 0,0201 , dan sub material sebesar 0,1627. Hasil penelitian menunjukan bahwa penerapan metode simpleks dapat menghasilkan solusi optimal bagi perusahaan, baik menyangkut pencapaian keuntungan maupun efisiensi biaya.
\end{abstract}

Kata kunci: Metode Simpleks; Mixing Design; Sinter Ore; Solusi Optimal; Minimasi

\begin{abstract}
Sintered ore is a semi-finished product in steel making. This product is produced from mixing raw materials in the sinter plant section to obtain a quality steel product's characteristics. Based on the identification of problems in the Sinter Plant section, it was found that the production process for sintered ore products was still inefficient. This is evidenced by the composition of the material resulting from the product design mixing tends to exceed the target properties of the mixing design process desired by the company. This study aims to find the value of efficiency in the production cost of sintered ore products and achieve the company's target properties of sintered ore products. The research was conducted using data on product characteristics, the target properties in the mixing design of sinter ore products in 2019. The calculation of mixing design used the simplex method. Data processing using the simplex method was carried out by iteratively eliminating five times the calculation until the optimal solution was obtained. The application of the simplex method in the process of mixing the design of sintered ore products results in a significant efficiency value for the company. The efficiency value that can be achieved is USD 1,050,210, based on reducing the cost of mixing design from USD 20,445,600 to USD $19,395,390$. The achievement of the target properties for material composition is almost close to the target, namely fines ore $A$ of 0.8997 , fines ore $B$ of 0 , fines ore $C$ of 0.0027 , a concentrate of 0.0201 , and sub material of 0.1627 . The results showed that applying the simplex method could produce optimal solutions for the company, both regarding the achievement of profits and cost-efficiency.
\end{abstract}

Keywords: Simpleks Method; Mixing Design; Sinter Ore; Optimal Solution; Minimization 


\section{PENDAHULUAN}

Sinter ore merupakan produk setengah jadi dalam pembuatan baja. Produk ini dihasilkan dari perpaduan (mixing) raw material dibagian sinter plant untuk mendapatkan karakteristik produk baja yang berkualitas. Sinter plant adalah bagian yang melakukan proses produksi dalam pembuatan produk sinter ore, yaitu produk setengah jadi dari proses pembuatan baja. Proses produksi sinter ore secara umum dapat dipahami dengan mudah dimana seluruh bahan baku dari produk sinter ore dicampur menjadi satu kemudian ditempatkan pada palet pemasakan. Selanjutnya dilakukan proses pembakaran dari bagian atas bahan baku sampai bagian bawah.

Proses pembakaran untuk menjadikan bahan baku tersebut setengah meleleh dan pada akhirnya dari sebagian lelehan bahan baku tersebut menyatu satu sama lain sehingga membentuk bongkahan seperti karang yang berongga. Prinsip pembuatan produk sinter ore ini mirip seperti prinsip pembakaran rokok. Masalah yang dihadapi perusahaan saat ini adalah biaya produksi mixing design belum efisien dan belum tercapainya target nilai properties mixing design produk sinter ore sebagaimana yang telah ditentukan oleh perusahaan. Disamping itu, belum adanya perbaikan metode mixing design produk sinter ore yang digunakan oleh perusahaan, sehingga belum diketahui apakah metode yang dipakai saat ini sudah termasuk metode yang optimal atau belum.

Penelitian ditujukan untuk menemukan solusi guna memperbaiki proses mixing design produk sinter ore dengan menggunakan metode yang tepat. Pemilihan metode yang tepat dalam melakukan mixing design sangat penting karena dapat mempengaruhi kualitas dan biaya produksi sehingga berimbas pada harga jual produk akhir. Oleh karena itu diperlukan upaya perbaikan untuk mendapatkan solusi optimal pada proses mixing design produk sinter ore. Perbaikan ini diharapkan dapat mencapai target efisiensi biaya produksi dan target properties mixing design produk sinter ore. Sebelum penelitian dilakukan biaya proses produksi sinter ore per bulan adalah sebesar 20.445.600 USD (dua puluh juta empat ratus empat puluh lima ribu enam ratus Dolar Amerika) dengan target properties produk sinter ore (Tabel 1).

Tabel 1. Biaya dan Target Properties Komposisi Kimia pada Mixing Design Produk Sinter Ore

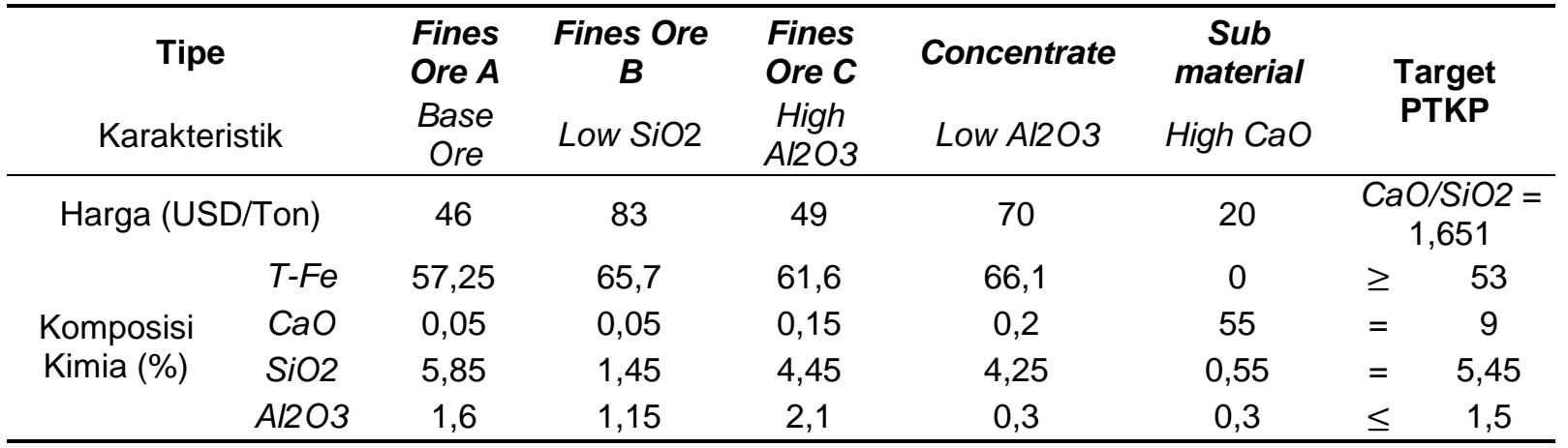

Tabel 2. Karakteristik Produk Sinter Ore Hasil Mixing Design

\begin{tabular}{ccccccc}
\hline \multirow{2}{*}{ Tipe } & $\begin{array}{c}\text { Mixing } \\
\text { Design } \\
\text { Saat Ini }\end{array}$ & $\begin{array}{c}\text { Komposisi Kimia (\%) } \\
\text { T-Fe (Total } \\
\text { Ferrous) }\end{array}$ & $\begin{array}{c}\text { CaO } \\
\text { (Calcium } \\
\text { Oxide) }\end{array}$ & $\begin{array}{c}\text { SiO2 } \\
\text { (Silica) }\end{array}$ & $\begin{array}{c}\text { Al2O3 } \\
\text { (Alumina) }\end{array}$ & $\begin{array}{c}\text { CaO/SiO2 } \\
\text { (Basisitas) }\end{array}$ \\
\hline Fines Ore A & 0,500 & 28,625 & 0,025 & 2,925 & 0,8 & \\
Fines Ore B & 0,080 & 5,256 & 0,004 & 0,116 & 0,092 & \\
Fines Ore C & 0,160 & 9,856 & 0,024 & 0,712 & 0,336 & \\
Concentrate & 0,120 & 7,932 & 0,024 & 0,51 & 0,036 & \\
Submaterial & 0,140 & 0 & 7,7 & 0,077 & 0,042 & \\
\hline Hasil & & 51,669 & 7,777 & 4,34 & 1,306 & 1,792 \\
\hline
\end{tabular}


Tabel 1 menunjukan 4 senyawa kimia yang dibutuhkan untuk menghasilkan produk sinter ore yaitu: T-Fe (total ferrous), $\mathrm{CaO}$ (Calcium Oxide), $\mathrm{SiO} 2$ (silicon dioxide atau silica) dan $\mathrm{Al} 2 \mathrm{O} 3$ (Aluminium Oxide atau Alumina). Keempat senyawa tersebut diperoleh dari pencampuran beberapa material yaitu: fines ore $\mathrm{A}$, fines ore $\mathrm{B}$, fines ore $\mathrm{C}$, concentrate dan sub material lain. Target properties komposisi kimia pada proses mixing design produk sinter ore adalah: T-Fe (total ferrous) harus lebih besar dari atau sama dengan 53, Cao (Calcium Oxide) sama dengan 9, SiO2 (silica) sama dengan 5,45 dan Al2O3 (alumina) kurang dari atau sama dengan 1,5 dengan target katalis $\mathrm{CaO} / \mathrm{SiO} 2$ sebesar 1,651. Sedangkan karakteristik produk sinter ore hasil mixing design saat ini masih belum mencapai target properties yang diinginkan (Tabel 2).

Hasil mixing design produk sinter ore (Tabel 2) masih belum sesuai dengan target yang diinginkan, dimana T-Fe (total ferrous) diperoleh sebesar 51,669 target seharusnya lebih besar dari atau sama dengan 53, Cao (calcium oxide) diperoleh 7,777 target seharusnya sama dengan $9, \mathrm{SiO} 2$ (silica) diperoleh 4,34 target seharusnya sama dengan 5,45, sedangkan Al2O3 (alumina) sudah sesuai target yaitu 1,306 dimana target untuk alumina adalah kurang dari atau sama dengan 1,5. Basisitas $\mathrm{CaO} / \mathrm{SiO} 2$ diperoleh 1,792 target seharusnya sebesar 1,651 .

Metode simpleks merupakan salah satu metode dalam linier programming untuk menentukan solusi optimal. Penentuan solusi optimal diperoleh dengan cara perhitungan iterative melalui pemeriksaan setiap titik ekstrim. Metode simpleks menjadi salah satu teknik pengambilan keputusan dalam mengalokasikan sumber daya perusahaan secara optimal (Meflinda and Mahyarni, 2011; Suryanto and Putra, 2019). Pencarian nilai optimal dalam metode simpleks berhubungan dengan banyak constraint dan variabel.

Kendala-kendala dalam metode simpleks dapat dapat dioptimalkan untuk meminimumkan atau memaksimumkan fungsi tujuan (Yuwono and Istiani, 2007). Penggunaan metode simpleks secara konsisten memberikan solusi optimal (Rumahorbo and Mansyur, 2016). Beberapa riset menunjukkan implementasi metode simpleks mampu meningkatkan kapasitas produksi (Nursanti et al., 2015; Supriyadi et al., 2017) yang berdampak pada peningkatan keuntungan bagi perusahaan (Aprilyanti et al., 2018; Saryoko, 2016; Sriwidadi and Agustina, 2013). Penggunaan metode simpleks juga dapat mengoptimalkan proses blending untuk meningkatkan kualitas batubara dan memenuhi kriteria permintaan konsumen (Syarif et al., 2013). Metode simpleks memiliki nilai konsistensi yang baik dalam penyelesaian nilai optimum dengan mendapatkan suatu titik tertentu dalam iterasi.

Implementasi metode simpleks dalam menyelesaikan permasalahan alokasi sumberdaya dan terbukti dapat memberikan solusi optimal untuk meningkatkan keuntungan perusahaan. Penelitian ini dilakukan untuk mengetahui implikasi penerapan metode simpleks dalam proses mixing design produk sinter ore pada perusahaan. Dengan menggunakan metode simpleks diharapkan dapat mengurangi biaya produksi produk sinter ore pada bagian Sinter Plant dengan tetap mempertahankan target properties produk yang telah ditetapkan oleh perusahaan. Pengurangan biaya diperoleh dengan melakukan rekayasa komposisi raw material yang digunakan dalam pembuatan produk sinter ore pada tahap mixing design.

\section{METODE PENELITIAN}

Penelitian dilakukan di salah satu perusahaan manufaktur yang bergerak dibidang produksi baja di Provinsi Banten. Penelitian dilakukan di area sinter plant dengan objek penelitian adalah produk sinter ore. Sinter plant merupakan bagian yang memproduksi produk sinter ore, yaitu produk setengah jadi dari proses pembuatan baja. secara umum dapat dipahami dengan mudah dimana seluruh bahan baku dari produk sinter ore dicampur menjadi satu kemudian ditempatkan pada palet pemasakan, kemudian dilakukan proses pembakaran dari bagian atas bahan baku sampai bagian bawah, proses pembakaran untuk menjadikan bahan baku tersebut setengah meleleh dan pada akhirnya dari sebagian lelehan bahan baku tersebut menyatu satu sama lain sehingga membentuk bongkahan seperti karang yang berongga.

Penelitian ini menggunakan data primer dan data sekunder. Data primer yang diambil dalam penelitian yaitu informasi terkait proses mixing design produk sinter ore. Proses pengambilan data dilakukan dengan wawancara pada sejumlah Supervisor Teknologi Sinter Plant. Data sekunder meliputi data data mixing design material, data komposisi material dan harga material. berikut:

Tahapan pengolahan data adalah sebagai

a. Menentukan fungsi tujuan

Fungsi tujuan dalam penelitian ini adalah menurunkan (minimasi) biaya produksi produk sinter ore pada tahap mixing design.

b. Menentukan fungsi pembatas

Hal yang menjadi fungsi pembatas dalam penelitian adalah senyawa kimia yang dipadukan yang terkandung dalam beberapa komponen produk yaitu: Total Ferrous, Calcium Oxide, Silica dan Alumina. 
c. Merubah persamaan simpleks kedalam bentuk baku atau standar

Setelah dilakukan perubahan persamaan kedalam bentuk standar, maka terdapat beberapa variabel variabel slack, variabel surplus dan variabel buatan (artificial variable).

d. Menentukan variabel keputusan

Adapun variabel keputusan dalam penelitian adalah material fines ore $\mathrm{A}$, fines ore $\mathrm{B}$, fines ore $\mathrm{C}$, Concentrate dan sub material lainnya.

e. Melakukan iterasi

Proses iterasi dilakukan dengan terlebih dahulu menentukan kolom pivot, baris pivot dan elemen (nilai) pivot. Banyaknya iterasi tergantung dari seberapa besar tingkat kompleksitas fungsi pembatas dan variabel keputusan pada masalah yang diselesaikan.

f. Menentukan solusi optimal

Solusi optimal dalam penelitian ini diperoleh setelah semua koefisien variabel pada persamaan fungsi tujuan bernilai kurang dari atau sama dengan nol $(Z \leq 0)$.

\section{HASIL DAN PEMBAHASAN}

Proses pengumpulan data secara langsung dilakukan dengan cara wawancara pada beberapa Supervisor Blast Furnace Planner and Sinter Technology. Wawancara yang dimaksudkan untuk menggali informasi sekaligus mengkonfirmasi data karakteristik produk dan target properties mixing design produk sinter ore. Data target properties mixing material tahun 2019 (Tabel 1). Data yang digunakan dalam proses mixing design menggunakan metode simpleks adalah data karakteristik material, data harga material, data target pencapaian dan data mixing material sinter ore saat ini.

Pengolahan data menggunakan metode simpleks terdiri dari beberapa tahapan, mulai dari penentuan fungsi tujuan sampai mendapatkan solusi optimal. Adapun tahapan pengolahan data nya adalah sebagai berikut:

1. Menentukan fungsi tujuan

Fungsi tujuan dari penelitian adalah minimasi biaya produksi produk sinter ore pada bagian Sinter Plant. Proses minimasi biaya dilakukan pada tahap analisis mixing design.

Bentuk umum:

Minimum Z $=46$ Fines Ore A + 83 Fines Ore B +49 Fines Ore $C+70$ Concentrate +20 Submaterial

Bentuk baku:

Minimum Z - 46 Fines Ore A - 83 Fines Ore B

- 49 Fines Ore C - 70 Concentrate - 20 Submaterial $=0$

2 Menentukan fungsi pembatas

a. T-Fe (Total Ferrous):

Bentuk umum:

57,25 Fines Ore A + 65,7 Fines Ore B +
61,6 Fines Ore C + 66,1 Concentrate +0 Submaterial $\geq 53$

Bentuk baku:

57,25 Fines Ore A + 65,7 Fines Ore B + 61,6 Fines Ore $C+66,1$ Concentrate +0 Submaterial + A $1-\operatorname{Sr} 1=53$

b. $\mathrm{CaO}$ (Calcium Oxide):

Bentuk umum:

0,05 Fines Ore A + 0,05 Fines Ore B + 0,15

Fines Ore $\mathrm{C}+0,2$ Concentrate +55

Submaterial $=9$

Bentuk baku:

0,05 Fines Ore $A+0,05$ Fines Ore $B+0,15$

Fines Ore $C+0,2$ Concentrate +55

Submaterial $+\mathrm{A} 2=9$

c. SiO2 (Silicon Dioxide atau Silica):

Bentuk umum:

5,85 Fines Ore A + 1,45 Fines Ore B + 4,45

Fines Ore $C+4,25$ Concentrate $+0,55$

Submaterial $=5,45$

Bentuk baku:

5,85 Fines Ore A + 1,45 Fines Ore B + 4,45

Fines Ore $C+4,25$ Concentrate $+0,55$

Submaterial $+\mathrm{A} 3=5,45$

d. $\mathrm{Al} 2 \mathrm{O} 3$ (Aluminium Oxide atau Alumina):

Bentuk umum:

1,6 Fines Ore $A+1,15$ Fines Ore $B+2,1$

Fines Ore $C+0,3$ Concentrate $+0,3$

Submaterial $\leq 1,5$

Bentuk baku:

1,6 Fines Ore $A+1,15$ Fines Ore $B+2,1$

Fines Ore $C+0,3$ Concentrate $+0,3$

Submaterial $+\mathrm{SI} 4=1,5$

3. Menentukan variabel keputusan

Fines Ore A, Fines Ore B, Fines Ore C Concentrate dan Submaterial, Sr 1, A 1, A 2, A $3, \mathrm{SI} 4 \geq 0$

Keterangan nama variabel:

Artificial $=\mathrm{A}$

Surplus $=\mathrm{Sr}$

Slack $=$ SI

4. Melakukan iterasi

Proses iterasi dilakukan sebanyak 5 kali, Hasil perhitungan iterasi dengan menggunakan metode simpleks ditunjukan pada Tabel 3.

5. Menentukan solusi optimal

Hasil iterasi ke-5 pada tabel 6 menunjukan bahwa solusi sudah optimal karena nilai koefisien variabel keputusan pada fungsi tujuan $Z \leq 0$ (kurang dari atau sama dengan nol). Koefisien masing-masing variabel yaitu: fines ore $\mathrm{A}$ bernilai 0 , fines ores B bernilai $-16,7004$, fines ore C bernilai 0 , concentrate bernilai 0 dan sub material bernilai 0 . Untuk memastikan bahwa analisis metode simpleks telah sesuai dengan target perusahaan yang diinginkan, selanjutnya dilakukan perhitungan mixing design (Tabel 4). 
Tabel 3. Hasil Perhitungan Iterasi Metode Simpleks

\begin{tabular}{|c|c|c|c|c|c|c|c|c|c|c|c|}
\hline $\begin{array}{c}\text { Variabel } \\
\text { Basis }\end{array}$ & $\begin{array}{c}\text { Fines } \\
\text { Ore A }\end{array}$ & $\begin{array}{l}\text { Fines } \\
\text { Ore B }\end{array}$ & $\begin{array}{l}\text { Fines } \\
\text { Ore C }\end{array}$ & Concent. & Submat. & A 1 & Sr 1 & A 2 & A 3 & SI 4 & $\begin{array}{c}\text { Jumlah } \\
\text { (Nilai } \\
\text { Kanan) }\end{array}$ \\
\hline Iteration 1 & & & & & & & & & & & \\
\hline Z & 63,15 & 67,2 & 66,2 & 70,55 & 55,55 & 0 & -1 & 0 & 0 & 0 & \\
\hline A 1 & 57,25 & 65,7 & 61,6 & 66,1 & 0 & 1 & -1 & 0 & 0 & 0 & 53 \\
\hline A 2 & 0,05 & 0,05 & 0,15 & 0,2 & 55 & 0 & 0 & 1 & 0 & 0 & 9 \\
\hline A 3 & 5,85 & 1,45 & 4,45 & 4,25 & 0,55 & 0 & 0 & 0 & 1 & 0 & 5,45 \\
\hline $\begin{array}{c}\text { SI } 4 \\
\text { Iteration } 2\end{array}$ & 1,6 & 1,15 & 0,3 & 0,3 & 0,3 & 0 & 0 & 0 & 0 & 1 & 1,5 \\
\hline Z & 2,0458 & $-2,9231$ & 0,453 & 0 & 55,55 & $-1,0673$ & 0,0673 & 0 & 0 & 0 & \\
\hline Concentrate & 0,8661 & 0,9939 & 0,9319 & 1 & 0 & 0,0151 & $-0,0151$ & 0 & 0 & 0 & 0,8018 \\
\hline A 2 & $-0,1232$ & $-0,1488$ & $-0,0364$ & 0 & 55 & $-0,003$ & 0,003 & 1 & 0 & 0 & 8,8396 \\
\hline A 3 & 2,169 & $-2,7743$ & 0,4893 & 0 & 0,55 & $-0,0643$ & $-0,0643$ & 0 & 1 & 0 & 2,0423 \\
\hline $\begin{array}{c}\text { SI } 4 \\
\text { Iteration } 3\end{array}$ & 1,3402 & 0,8518 & 1,8204 & 0 & 0,3 & $-0,0045$ & 0,0045 & 0 & 0 & 1 & 1,2595 \\
\hline Z & 2,1703 & $-2,7728$ & 0,4897 & 0 & 0 & $-1,0643$ & 0,0643 & $-1,01$ & 0 & 0 & \\
\hline Concentrate & 0,8661 & 0,9939 & 0,9319 & 1 & 0 & 0,0151 & $-0,0151$ & 0 & 0 & 0 & 0,8018 \\
\hline Submaterial & $-0,0022$ & $-0,0027$ & $-0,0007$ & 0 & 1 & $-0,0001$ & 0,0001 & 0,0182 & 0 & 0 & 0,1607 \\
\hline A 3 & 2,1703 & $-2,7728$ & 0,4897 & 0 & 0 & $-0,0643$ & 0,0643 & $-0,01$ & 1 & 0 & 1,9539 \\
\hline $\begin{array}{c}\text { SI } 4 \\
\text { Iteration } 4\end{array}$ & 1,3408 & 0,8526 & 1,8206 & 0 & 0 & $-0,0045$ & 0,0045 & $-0,0055$ & 0 & 1 & 1,2112 \\
\hline Z & 0 & 5,1541 & 12,9307 & 0 & 0 & 1,4897 & $-1,4897$ & 0,4308 & $-6,7195$ & 0 & \\
\hline Concentrate & 0 & 2,1005 & 0,7365 & 1 & 0 & 0,0408 & $-0,0408$ & 0,004 & $-0,3991$ & 0 & 0,0221 \\
\hline Submaterial & 0 & $-0,0056$ & $-0,0002$ & 0 & 1 & $-0,0001$ & 0,0001 & 0,0182 & 0,001 & 0 & 0,1627 \\
\hline Fines Ore A & 1 & $-1,2776$ & 0,2256 & 0 & 0 & $-0,0296$ & 0,0296 & $-0,0046$ & 0,4608 & 0 & 0,9003 \\
\hline $\begin{array}{c}\text { SI } 4 \\
\text { Iteration } 5\end{array}$ & 0 & 2,5657 & 1,5181 & 0 & 0 & 0,0352 & $-0,0352$ & 0,0007 & $-0,6178$ & 1 & 0,0041 \\
\hline Z & 0 & $-16,7004$ & 0 & 0 & 0 & 1,1901 & $-1,1901$ & 0,4247 & $-1,457$ & $.8,5179$ & \\
\hline Concentrate & 0 & 0,8558 & 0 & 1 & 0 & 0,0237 & 0,0237 & 0,0036 & $-0,0993$ & $\cdot 0,4851$ & 0,0201 \\
\hline Submaterial & 0 & $-0,0053$ & 0 & 0 & 1 & $-0,0001$ & 0,0001 & 0,0182 & 0,001 & 0,0001 & 0,1627 \\
\hline Fines Ore A & 1 & $-1,659$ & 0 & 0 & 0 & $-0,0348$ & 0,0348 & $-0,0047$ & 0,5526 & $\cdot 0,1486$ & 0,8997 \\
\hline Fines Ore C & 0 & 1,6901 & 1 & 0 & 0 & 0,0232 & $-0,0232$ & 0,0005 & $-0,407$ & 0,6587 & 0,0027 \\
\hline
\end{tabular}

Tabel 4. Hasil Mixing Design dengan Metode Simpleks

\begin{tabular}{ccccccc}
\hline \multirow{2}{*}{ Tipe } & \multirow{2}{*}{ Mixing Design Metode Simpleks } & \multicolumn{5}{c}{ Komposisi Kimia (\%) } \\
& T-Fe & CaO & SiO2 & Al2O3 & CaO/SiO2 \\
\hline Fines Ore A & 0,8997 & 51,508 & 0,045 & 5,263 & 1,44 & \\
Fines Ore B & 0,000 & 0 & 0 & 0 & 0 & \\
Fines Ore C & 0,0027 & 0,166 & 0,0004 & 0,012 & 0,006 & \\
Concentrate & 0,0201 & 1,329 & 0,004 & 0,085 & 0,006 & \\
Submaterial & 0,1627 & 0 & 8,949 & 0,089 & 0,049 & \\
\hline & Total & 53,003 & 8,998 & 5,45 & 1,5 & 1,651 \\
\hline
\end{tabular}

Contoh perhitungan mixing design Tabel 4 adalah sebagai berikut:

1. Nilai T-Fe

Fines Ore $\mathrm{A}=$ Komposisi Kimia $\times$ Mixing design $=57,25 \times 0,8997=51,508$

Fines Ore $\mathrm{B}=$ Komposisi Kimia $\times$ Mixing design $=65,7 \times 0=0$

Fines Ore $\mathrm{C}=$ Komposisi Kimia $\times$ Mixing design $=61,6 \times 0,0027=0,166$

Concentrate $=$ Komposisi Kimia $\times$ Mixing design $=66,1 \times 0,0201=1,329$

Submaterial $=$ Komposisi Kimia $\times$ Mixing design $=0 \times 0,1627=0$

Total T-Fe $=$ hasil penjumlahan dari nilai $\mathrm{T}-\mathrm{Fe}$ seluruh material $=51,508+0+0,166+1,329$ $+0=53,003$
2. Nilai $\mathrm{CaO}$

Fines Ore $A=$ Komposisi Kimia $\times$ Mixing design $=0,05 \times 0,8997=0,045$

Fines Ore $\mathrm{B}=$ Komposisi Kimia $\times$ Mixing design $=0,05 \times 0=0$

Fines Ore $\mathrm{C}=$ Komposisi Kimia $\times$ Mixing design $=0,15 \times 0,0027=0,0004$

Concentrate $=$ Komposisi Kimia $\times$ Mixing design $=0,20 \times 0,0201=0,004$

Submaterial $=$ Komposisi Kimia $\times$ Mixing design $=55 \times 0,1627=8,949$

Total $\mathrm{CaO}=$ hasil penjumlahan dari nilai $\mathrm{CaO}$ seluruh material $=0,045+0+0,0004+0,004$ $+8,949=8,998$

3. Nilai $\mathrm{SiO} 2$

Fines Ore $A=$ Komposisi Kimia $\times$ Mixing 
design $=5,85 \times 0,8997=5,263$

Fines Ore $\mathrm{B}=$ Komposisi Kimia $\times$ Mixing design $=1,45 \times 0=0$

Fines Ore $\mathrm{C}=$ Komposisi Kimia $\times$ Mixing design $=4,45 \times 0,0027=0,012$

Concentrate $=$ Komposisi Kimia $\times$ Mixing design $=4,25 \times 0,0201=0,085$

Submaterial $=$ Komposisi Kimia $\times$ Mixing design $=0,55 \times 0,1627=0,089$

Total $\mathrm{SiO} 2=$ hasil penjumlahan dari nilai $\mathrm{SiO} 2$ seluruh material $=5,263+0+0,012+$ $0,085+0,089=5,45$

4. Nilai $\mathrm{Al} 2 \mathrm{O} 3$

Fines Ore $\mathrm{A}=$ Komposisi Kimia $\times$ Mixing design $=1,60 \times 0,8997=1,44$

Fines Ore $\mathrm{B}=$ Komposisi Kimia $\times$ Mixing design $=1,15 \times 0=0$

Fines Ore $\mathrm{C}=$ Komposisi Kimia $\times$ Mixing design $=2,10 \times 0,0027=0,006$

Concentrate $=$ Komposisi Kimia $\times$ Mixing design $=0,30 \times 0,0201=0,006$

Submaterial $=$ Komposisi Kimia $\times$ Mixing design $=0,30 \times 0,1627=0,049$

Total $\mathrm{Al} 2 \mathrm{O} 3=$ hasil penjumlahan dari nilai Al2O3 seluruh material $=1,44+0+0,006+$ $0,006+0,049=1,5$

Nilai $\mathrm{CaO} / \mathrm{SiO} 2: \mathrm{CaO} / \mathrm{SiO} 2=8,998 / 5,45=$ 1,651 .

Hasil analisis metode simpleks mampu memberikan hasil perhitungan komposisi sinter ore sesuai target properties yang ditetapkan oleh perusahaan yaitu: T-Fe (Total Ferrous) sebesar 53,003, CaO (Calcium Oxide) sebesar 8,998, $\mathrm{SiO} 2$ (Silicon Dioxide atau Silica) sebesar 5,45 dan Al2O3 (Aluminium Oxide atau Alumina) sebesar 1,5 dan basisitas $\mathrm{CaO} / \mathrm{SiO} 2$ sebesar 1,6509 (Tabel 5). Capaian efisiensi yang diperoleh dari hasil penelitian adalah sebesar 1.050.210 USD per bulan. Efisiensi ini diperoleh karena tidak digunakannya material fines ore B pada proses mixing produk sinter ore. Biaya rata-rata perbulan semula sebesar 20.445.600 USD berkurang menjadi 19.395.390 USD per bulan (Tabel 6 dan Tabel 7).

Tabel 5. Perbandingan Hasil Mixing Design Metode Perusahaan dengan Metode Simpleks

\begin{tabular}{|c|c|c|c|c|c|}
\hline $\begin{array}{l}\text { Properties } \\
\text { Component (\%) } \\
\text { Target Perusahaan } \\
(\%)\end{array}$ & $T-F e$ & $\mathrm{CaO}$ & $\begin{array}{l}\text { SiO2 } \\
5,45\end{array}$ & $\begin{array}{l}\text { Al2 } \\
\text { O3 } \\
\leq 1,5\end{array}$ & C/S \\
\hline $\begin{array}{l}\text { Mix Design Metode } \\
\text { Perusahaan }\end{array}$ & ,67 & 7,78 & & 1,31 & 1,7 \\
\hline $\begin{array}{l}\text { Mix Design Metode } \\
\text { Simpleks }\end{array}$ & 3,003 & 8 & 4 & 1,5 & 1,6509 \\
\hline
\end{tabular}

Keberhasilan metode simpleks dalam pencapaian efisiensi biaya produksi pada proses mixing design produk sinter ore selaras dengan hasil penelitian sebelumnya (Alfian et al., 2020; Arnanda et al., 2016; Chonani et al., 2014), perbedaannya hanya terletak pada besarnya laba atau nilai efisiensi yang dihasilkan. Dimana pada penelitian ini disamping mendapatkan efisiensi yang besar juga tercapainya target properties mixing produk sinter ore sehingga perusahaan mendapatkan dua keuntungan yang diperoleh dari penerapan metode simpleks. Nilai efisiensi ini akan berdampak pada peningkatan keuntungan yang diperoleh perusahaan (Aulia et al., 2013; Hakim et al., 2018).

Tabel 6. Biaya Mixing Design Perusahaan

\begin{tabular}{cccccc}
\hline Tipe & $\begin{array}{c}\text { Harga } \\
\text { (USD/Ton) }\end{array}$ & $\begin{array}{c}\text { Mixing } \\
\text { design } \\
\text { Saat Ini }\end{array}$ & $\begin{array}{c}\text { New Raw } \\
\text { Material }\end{array}$ & $\begin{array}{c}\text { Biaya Raw } \\
\text { Material } \\
\text { Perhari (USD) }\end{array}$ & $\begin{array}{c}\text { Biaya Raw } \\
\text { Material } \\
\text { Perbulan (USD) }\end{array}$ \\
\hline Fines Ore A & 46 & 0,5 & & 322.000 & 9.660 .000 \\
Fines Ore B & 83 & 0,08 & & 92.960 & 2.788 .800 \\
Fines Ore C & 49 & 0,16 & 14.000 & 109.760 & 3.292 .800 \\
Concentrate & 70 & 0,12 & & 117.600 & 3.528 .000 \\
Submaterial & 20 & 0,14 & & 39.200 & 1.176 .000 \\
\hline \multicolumn{7}{c}{ Total } & & 681.520 & 20.445 .600 \\
\hline
\end{tabular}

Tabel 7. Biaya mixing design dengan Metode Simpleks

\begin{tabular}{cccccc}
\hline Tipe & $\begin{array}{c}\text { Harga } \\
\text { (USD/Ton) }\end{array}$ & $\begin{array}{c}\text { Mixing design } \\
\text { Metode Simpleks }\end{array}$ & $\begin{array}{c}\text { New Raw } \\
\text { Material }\end{array}$ & $\begin{array}{c}\text { Biaya Raw Material } \\
\text { Perhari (USD) }\end{array}$ & $\begin{array}{c}\text { Biaya Raw Material } \\
\text { Perbulan (USD) }\end{array}$ \\
\hline Fines Ore A & 46 & 0,8997 & & 579.407 & 17.382 .204 \\
Fines Ore B & 83 & 0 & 0 & 0 \\
Fines Ore C & 49 & 0,0027 & 14.000 & 1.852 & 55.566 \\
Concentrate & 70 & 0,0201 & & 19.698 & 590.940 \\
Submaterial & 20 & 0,1627 & & 45.556 & 1.366 .680 \\
\hline \multicolumn{7}{r}{ Total } & & 646.513 & 19.395 .390 \\
\hline
\end{tabular}




\section{KESIMPULAN}

Penerapan metode simpleks dalam pengolahan mixing design produk sinter ore memberikan dampak perbaikan dalam pencapaian efisiensi bagi perusahaan. Nilai efisiensi diperoleh sebesar 1.050.210 USD, berdasarkan penurunan biaya mixing design dari 20.445.600 USD menjadi sebesar 19.395.390 USD. Pencapaian properties komposisi material secara signifikan mendekati target yang ditetapkan oleh perusahaan yaitu fines ore A sebesar 0,8997 , fines ore B sebesar 0 , fines ore $C$ sebesar 0,0027 , concentrate sebesar 0,0201 , dan sub material sebesar 0,1627 . Hasil penelitian menunjukan bahwa penerapan metode simpleks secara efektif dapat memberikan solusi optimal yang menyangkut pencapaian keuntungan maupun efisiensi biaya. Penelitian lanjutan dapat menggunakan Fuzzy linier programming untuk mendapatkan hasil yang lebih optimal.

\section{DAFTAR PUSTAKA}

Alfian, A., Hastarina, M., and Wahyudi, B. (2020). Perencanaan Produksi dengan Metode Simpleks Untuk Memaksimalkan Keuntungan (Studi Kasus UKM Mebel Urang Tobo). Integrasi: Jurnal IImiah Teknik Industri, 1(1), 1-8. https://jurnal.umpalembang.ac.id/integrasi/article/view/2963

Aprilyanti, S., Pratiwi, I., and Basuki, M. (2018). Optimasi Keuntungan Produksi Kemplang Panggang Menggunakan Linear Programming Melalui Metode Simpleks. Seminar Dan Konferensi Nasional IDEC, 111. https://idec.ft.uns.ac.id/wpcontent/uploads/2018/05/ID038.pdf

Arnanda, R., Hadi, S., and Yulida, R. (2016). Efisiensi Produksi Padi di Kecamatan Kuala Kampar Kabupaten Pelalawan. Sorot, 11(2), 111-126.

https://sorot.ejournal.unri.ac.id/index.php/JS /article/view/3889

Aulia, M. R., Putra, D. N., Murniati, S., Mustahiroh, M., Octavia, D., and Budiasih, Y. (2013). Maksimalisasi Keuntungan Dengan Pendekatan Metode Simpleks Studi Kasus pada Pabrik Sendai X di Ciputat, Tangerang Selatan. Liquidity, 2(2), 144-150. http://ojs.itb-

ad.ac.id/index.php/LQ/article/view/116

Chonani, S. H., Prasmatiwi, F. E., and Santoso, H. (2014). Efisiensi Produksi dan Pendapatan Usahatani Cabai Merah di Kecamatan Metro Kibang Kabupaten Lampung Timur: Pendekatan Fungsi Produksi Frontier. Jurnal IImu-IImu Agribisnis, 2(2), 95-102. http://jurnal.fp.unila.ac.id/index.php/JIA/articl e/view/730
Hakim, L., Paramu, H., and Gusminto, E. B. (2018). Penerapan Linear Programming dalam Penentuan Kombinasi Produk Guna Memaksimalkan Laba Pada UD Putera Sroedji Jember. BISMA: Jurnal Bisnis Dan Manajemen, 12(3), 300-312. https://doi.org/10.19184/bisma.v12i3.9000

Meflinda, A., and Mahyarni, M. (2011). Operations Research. Pekanbaru: UR Press.

Nursanti, E., Purnama, R. I., and Suardika, I. B. (2015). Optimasi Kapasitas Produksi untuk Mendapatkan Keuntungan Maksimum dengan Linear Programming. Performa: Media IImiah Teknik Industri, 14(1), 61-68. https://jurnal.uns.ac.id/performa/article/view/ 11020

Rumahorbo, R. L., and Mansyur, A. (2016). Konsistensi metode simpleks dalam menentukan nilai optimum. KARISMATIKA: Kumpulan Artikel IImiah, Informatika, Statistik, Matematika Dan Aplikasi, 3(1), 3646.

Saryoko, A. (2016). Metode Simpleks Dalam Optimalisasi Hasil Produksi. Informatics for Educators and Professional: Journal of Informatics, 1(1), 27-36. http://ejournalbinainsani.ac.id/index.php/ITBI/article/view/ 140

Sriwidadi, T., and Agustina, E. (2013). Analisis Optimalisasi Produksi dengan Linear Programming Melalui Metode Simpleks. Binus Business Review, 4(2), 725-741. https://journal.binus.ac.id/index.php/BBR/art icle/view/1386

Supriyadi, S., Muslimat, A., Pratama, R., and Ramayanti, G. (2017). Implementasi Linear Programming Untuk Memaksimalkan Keuntungan. Prosiding Seminar Nasional Riset Terapan/ SENASSET, 183-189. https://e-

jurnal.Ippmunsera.org/index.php/senasset/a rticle/view/446

Suryanto, E. S. N., and Putra, R. A. K. (2019). Analisis optimasi keuntungan dalam produksi keripik daun singkong dengan linier programming melalui metode simpleks. JURNAL MANAJEMEN, 11(2), 226-236. http://journal.feb.unmul.ac.id/index.php/JUR NALMANAJEMEN/article/view/5718

Syarif, M. I., Widodo, S., and Husain, J. R. (2013). Upaya optimalisasi proses blending untuk meningkatkan kualitas batubara dan memenuhi kriteria permintaan konsumen. Jurnal Geosains, 9(1), 41-47.

Yuwono, B., and Istiani, P. N. (2007). Bahan Kuliah Riset Operasional. Yogyakarta: UPN Veteran Yogyakarta. 